\title{
p53 IMMUNOSTAINING PATTERN IN BRAZILIAN PATIENTS WITH HEPATOCELLULAR CARCINOMA
}

\author{
Venâncio Avancini Ferreira ALVES(1), Marcelo Eidi NITA(2), Flair José CARRILHO(3), Suzane Kioko ONO-NITA(3), Alda WAKAMATSU(1), \\ Dárcio Matenhauer LEHRBACH(2), Maria Fernanda Pimentel de CARVALHO(2), Evandro Sobroza DE MELLO(1), \\ Luiz Carlos da Costa GAYOTTO(1) \& Luiz Caetano DA SILVA(3)
}

\begin{abstract}
SUMMARY
Hepatocellular carcinoma (HCC) is an important type of cancer etiologically related to some viruses, chemical carcinogens and other host or environmental factors associated to chronic liver injury in humans. The tumor suppressor gene p53 is mutated in highly variable levels (0-52\%) of HCC in different countries. OBJECTIVE. The objective of the present study was to compare the frequency of aberrant immunohistochemical expression of p53 in HCC occurring in cirrhotic or in non-cirrhotic patients as well as in liver cell dysplasia and in adenomatous hyperplasia. We studied 84 patients with HCC or cirrhosis. RESULTS. We detected p53 altered immuno-expression in $58.3 \%$ of patients in Grade III-IV contrasting to $22.2 \%$ of patients in Grade I-II $(\mathrm{p}=0.02)$. Nontumorous areas either in the vicinity of HCC or in the 30 purely cirrhotic cases showed no nuclear p53 altered expression, even in foci of dysplasia or adenomatous hyperplasia. No significant difference was found among cases related to HBV, HCV or alcohol. CONCLUSION. The high frequency of p53 immunoexpression in this population is closer to those reported in China and Africa, demanding further studies to explain the differences with European and North American reports.
\end{abstract}

KEYWORDS: Liver cancer; p53; Cell cycle; Apoptosis; Hepatitis B; Hepatitis C; Immunohistochemistry.

\section{INTRODUCTION}

Hepatocellular Carcinoma (HCC) is the most frequent type of primary liver cancer and one of the commonest cancers worldwide, and, in some countries in Asia and Africa, a leading cause of deaths ${ }^{50}$. Due to its heterogeneous geographical distribution, $\mathrm{HCC}$ has been instrumental in the identification of major risk factors. HCC is etiologically linked to viruses (Hepatitis B and Hepatitis C), chemical carcinogens (aflatoxins) and other host or environmental factors that cause chronic liver injury $\mathrm{y}^{8,9,45}$. These factors trigger a sequence of events leading to malignant transformation of liver parenchymal cells. Indeed, the previously normal liver (quiescent cells) after chronic exposure to different risk factors, in advanced stages of cirrhosis with repetitive bouts of cell death, regeneration and proliferation acquire preneoplastic features. The oxidative stress and the inflammatory cytokines liberation triggered by this process may cause serious genetic lesions that govern cell proliferation (clonal distribution) and the genesis of the tumour.

Since 1991, genetic studies have shown high prevalence of point mutations in p53 in southern Africa and in the region of Qidong, China, areas with high prevalence of viral infections as well as high concentration of aflatoxins in dietary intake $e^{23,30}$. The prevalence is much lower in other parts of the world.
Cancer cells are characterized by unrestrained growth which may be due to an imbalance between cell proliferation and death. Recently, several studies have shown that various types of alterations in cell cycle regulators are found in many kinds of cancer. p21 Waf1/Cip1 (p21) and p27 $7^{\text {Kip1 }}$ (p27) are part of this cell cycle regulators ${ }^{31}$. They belong to a family of genes, which negatively regulate the cell cycle, therefore, inhibiting the cell proliferation. The cell cycle is positively controlled by complex of cyclins and cyclin-dependent kinases $(\mathrm{CDK})^{11,50}$. The main substrate of cyclin and $\mathrm{CDK}$ is the retinoblastoma gene product $(\mathrm{Rb})$. Phosphorylation of $\mathrm{Rb}$ by cyclin/CDK complex allows progression of the cell cycle. p21 and $\mathrm{p} 27$ by binding to cyclin/CDK abrogate their activity ${ }^{40,41,43}$. Consequently, $\mathrm{Rb}$ is not phosphorylated and cell cycle progression is arrested. Hence, p21 and p27 are small proteins that have the ability to halt the cell cycle proliferation by inhibiting the cyclin/CDK complex, acting as tumour growth suppressors. Loss or decreased expressions of p21 and/or p27 may facilitate the proliferation of cancer cells.

It is accepted that cancer proceeds through the accumulation of mutations in genes that govern cell proliferation and death. In recent years, the most commonly observed genetic alterations in HCC, as well as in many other tumours affecting humans, have been reported to be the mutations of p53 gene ${ }^{50}$. 


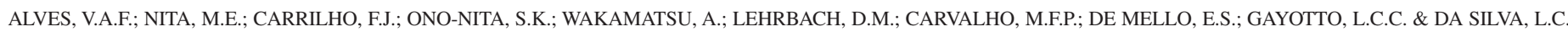
- p53 immunostaining pattern in Brazilian patients with hepatocellular carcinoma. Rev. Inst. Med. trop. S. Paulo, 46(1):25-31, 2004.

The anti-oncogene $\mathrm{p} 53$ is located on chromosome $17 \mathrm{p}$ and contains 11 exon interrupted by 10 introns, down-regulates cell proliferation by coding for a nuclear phosphoprotein which binds to specific DNA sequencies, arresting cell growth at late G1 phase of the cell cycle. This protein has a half-life of about 20 minutes and so is not regularly detectable by immunohistochemistry (IHC).

Most p53 mutations are missense and produce a faulty protein called mp53, functionally inactive but chemically stable. So, this gene has the features of a tumour suppressor gene in its wild type form and can be a dominant oncogene in its mutated form. Since its discovery two decades ago, the diverse role of $\mathrm{p} 53$ provided an explanation why mutations in this gene drive a normal cell towards cancer ${ }^{31}$.

The most common techniques used for p53 mutation detection include PCR based assays like Single Strand Conformational Polymorphism (SSCP), Denaturing Gradient Gel Electrophoresis (DGGE) $^{26}$ and DNA Sequencing. Recently, another method based on yeast functional assay was developed to detect p53 mutations. However, most genetic alterations are point mutations between codons 120 and 290 of the 393 amino-acid residues leading to mp53 and these can be detectable in the liver cell nucleus by IHC.

The p53 gene is mutated in about $27 \%$ of HCCs worldwide ${ }^{11}$. All reported p53 mutations in HCC are somatic; therefore, germ line mutations of p53 appear not to predispose to HCC. Recently, the p53 overexpression was associated with poor prognosis in patients with $\mathrm{HCC}^{28}$.

Both the frequency and the type of p53 mutations are different depending on geographic location and suspected etiology of these tumors. The frequency of all p53 mutations varies between 0 to $20 \%$ in North America and Europe and 42 to $52 \%$ in China. Although these mutations may be present independent of HBV or HCV infection, some studies describes higher indexes with aflatoxin exposure, either alone or associated to viral infections ${ }^{50}$ (Table 1).

The mutational spectrum of p53 gene associated to a given tumor is important in the etiology of cancer and it can be exploited to therapeutic and prognostic aims. Cancers presenting p53 mutations tend to be more aggressive and chemotherapy resistant than cancer of similar tissues expressing wild type p53.

Since most missense mutations of p53 produce stable protein, high levels of agreement are shown between IHC and genetic studies. However, a mutant case could result negative at IHC due to excessive fixation or when the genetic alteration is a delection or a non-sense mutation, with no production of any 553 protein.

On the opposite, IHC may result positive in the absence of mutation, for instance when there is an abnormal accumulation of non-mutated p53 protein, most probably related to post-transcriptional phenomena.

Table 1

Frequency and type of alteration and the methodology applied worldwide *

\begin{tabular}{|c|c|c|c|c|c|}
\hline Geographical area & Alteration rate & Affected codon & Method & Correlations & Ref. \\
\hline United States & $\begin{array}{c}6 / 30 \\
(20 \%)\end{array}$ & exons 4-8 & IHC, SSCP & $\mathrm{HCV}$ & 28 \\
\hline Alaska & $0 / 13$ & - & PCR sequence & - & 13 \\
\hline Japan & $\begin{array}{c}123 / 439 \\
(28 \%)\end{array}$ & exons 5-8 & $\begin{array}{l}\text { SSCP, PCR } \\
\text { sequence }\end{array}$ & $\begin{array}{l}17 p \text { and } 13 q \text { LOHs, viral hepatitis, } \\
\text { late tumor stage, large tumor gradelarge } \\
\text { tumor size, poor differentiation }\end{array}$ & 21 \\
\hline Thailand & $\begin{array}{c}2 / 15 \\
(13 \%)\end{array}$ & 249,254 & PCR sequence & 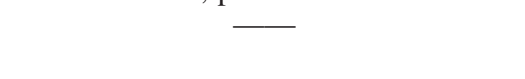 & 22 \\
\hline China (Qidong/ Shanghai) & $\begin{array}{l}73 / 139 \\
(52 \%)\end{array}$ & Mostly 249 & PCR sequence & HBV, AFB1, 17p LOH, 4q LOH & 20,47 \\
\hline China (Hong Kong) & $\begin{array}{l}6 / 21 \\
(29 \%)\end{array}$ & $\begin{array}{l}\text { exons 5-9 } \\
(249: 13 \%)\end{array}$ & PCR sequence & Progression & 37 \\
\hline Taiwan & $\begin{array}{l}66 / 211 \\
(31 \%)\end{array}$ & $\begin{array}{l}\text { exons } 5-8 \\
(249: 13 \%)\end{array}$ & $\begin{array}{l}\text { PCR sequence, } \\
\text { SSCP, IHC }\end{array}$ & Late tumor stage, HBV/AFB1/249 & 15 \\
\hline Germany & $\begin{array}{l}10 / 55 \\
(18 \%)\end{array}$ & exons $5-8$ & $\begin{array}{l}\text { SSCP, PCR, } \\
\text { cloning }\end{array}$ & - & 31 \\
\hline Britain & $\begin{array}{l}59 / 231 \\
(25 \%)\end{array}$ & exons $5-8$ & SSCP, DGGE & $\begin{array}{l}\text { Viral hepatitis, poor prognosis } \\
\text { haemochromatosis }(220)\end{array}$ & 10 \\
\hline France & $\begin{array}{c}9 / 58 \\
(15 \%)\end{array}$ & - & IHC & Viral hepatitis, tumor size, invasion & 32 \\
\hline Spain & $0 / 129$ & - & SSCP, IHC & - & 5 \\
\hline Mozambique & $\begin{array}{c}5 / 10 \\
(50 \%), 249\end{array}$ & 249 & PCR sequence & 17P LOH, AFB1 & 6 \\
\hline Senegal & $\begin{array}{c}10 / 15 \\
(67 \%), 249\end{array}$ & 249 & PCR sequence & AFB1 & 12 \\
\hline Australia & $0 / 15$ & - & PCR sequence & - & 50 \\
\hline
\end{tabular}

* Modified from BUENDIA, $2000^{7}$. 


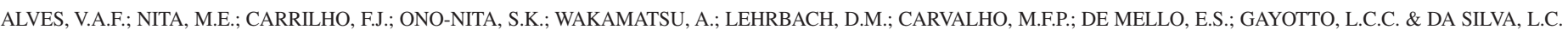
- p53 immunostaining pattern in Brazilian patients with hepatocellular carcinoma. Rev. Inst. Med. trop. S. Paulo, 46(1):25-31, 2004.

Since major functions of $\mathrm{p} 53$ in the cell cycle and cell transformation are performed directly by its protein, IHC may serve as a very useful tool for the study of $\mathrm{p} 53$ alterations in carcinogenesis ${ }^{57}$.

The development of HCC appears to be preceded by liver cell dysplasia, a condition subject to controversy and confusion. First, ANTHONY et al. $^{3}$ suggested the preneoplastic capacity of liver cell dysplasia and then several studies have stressed the relation with carcinoma. Recently, LIBBRECHT et al. ${ }^{38}$ investigated the predictive value of small and large cell dysplasia, revealing large cell dysplasia as an identifier of patients at risk for developing HCC.

In Japan, the presence of a large regenerative nodule within a cirrhotic liver, referred to as a macroregenerative nodule or adenomatous hyperplasia is thought to play a role in the pathogenesis of hepatocellular carcinoma ${ }^{4}$. In hepatocarcinogenesis of the cirrhotic liver, several Japanese authors suggest that the adenomatous hyperplasia might be the first step in the development of HCC, going through phases of dysplasic nodule and small HCC in a multistep fashion ${ }^{4,34,48}$.

The objective of the present study was to compare the frequency of abnormal immunohistochemical expression of $\mathrm{p} 53$ phosphoprotein in HCC occurring in cirrhotic versus non-cirrhotic patients as well as in large liver cell dysplasia (large cell dysplasia) and in adenomatous hyperplasia.

\section{CASUISTIC AND METHODS}

We studied 84 patients with hepatocellular carcinoma or cirrhosis. 54 patients were cases of hepatocellular carcinoma; 39 of them were cirrhotic and 15 non-cirrhotic patients. The other 30 patients were cirrhotic patients without hepatocellular carcinoma. Records were retrieved from the Hepatology Branch, Department of Gastroenterology or Division of Pathology of Hospital das Clínicas, São Paulo University School of Medicine.

Immunohistochemical data analysis: All reactions were performed at the Immunohistochemistry Laboratory, Adolfo Lutz Institute, the Public Health Laboratory, São Paulo, Brazil.

The following primary monoclonal antibodies used were DO-7 (Dako, USA), 1801 (Bio-gennex, USA) and DO-1 (Santa Cruz, USA). The epitopes recognized by the antibodies are located between the $\mathrm{N}$-terminal amino acids 1-45 (DO-7), 46-55 (1801) and 37-45 (DO-1) of the human p53 protein. Four-micrometer-thick histopathological sections were prepared from formalin-fixed paraffin-embedded tru-cut needle liver biopsies. Antigen retrieval was achieved with pressure cooker for 3 minutes. The specimens were incubated overnight with the primary antibody at $4{ }^{\circ} \mathrm{C}$. Amplification was achieved by streptavidin-biotin-peroxidase (Dako Duet, USA) and, in 4 cases with cytoplasmic p53 staining where samples were still available, a new reaction amplified with polymer-enzyme Envision-Alkaline Phosphatase System (Dako, USA) was performed, thus assuring that reactivity was not due to endogenous peroxidase or biotin (Fig. 1). The reaction products of peroxidase were visualized by amplification with avidin-biotin-peroxidase complex (Vector Laboratories, USA) and developed with $\mathrm{H}_{2} \mathrm{O}_{2}$ and diaminobenzidine (Sigma Corp., USA).

One observer (VAFA) blinded to the clinical outcome of patients performed assessment of staining ${ }^{21}$.
Chi square test was used for statistical analysis. All $p$ values reported are for a two-sided test, and the level of significance was set at 0.05 .

\section{RESULTS}

In the present study, antibodies DO-7 and DO-1 yielded quite similar results, with sharp nuclear staining in many neoplastic hepatocytes and occasionally also in the cytoplasm of some tumor cells. Antibody 1801 was shown less sensitive with fewer cases positive, showing rather faible nuclear staining.

In our sample, considering all the 54 patients with $\mathrm{HCC}, \mathrm{p} 53$ immuno-expression was found in 19 patients (35.2\%) (Fig. 1). Out of 39 cirrhotic patients with HCC, nuclear p53 expression was detected in $13(33.3 \%)$. The comparison of p53 immuno-expression in 6 of 27 well and moderately differentiated HCC (grades I or II) ${ }^{19,35,39}$ versus the 7 of 12 poorly differentiated (grades III or IV) ${ }^{18,30,34}$ a statistically significant difference in the results obtained (Fig. 2). Nontumorous areas either in the vicinity of $\mathrm{HCC}$ or in the 30 purely cirrhotic cases showed no p53 expression, even in foci of large cell dysplasia or adenomatous hyperplasia. The reproducibility of this staining pattern in the 4 cases where samples were still available for reaction with the recently introduced Envision System-Alkaline Phosphatase demonstrate this is a genuine pattern. These data shows a very high immuno-expression of abnormal p53 in Brazilian patients mostly in those with high-grade advanced tumors suggesting that p53 alteration occurs late in the carcinogenesis. When we considered HBV, HCV or alcohol in the cases studied, no significant difference was detected. In the noncirrhotic HCC group the p53 expression was detected in 6 in 15 cases (40\%), slightly higher than in those occurring in cirrhotic patients.

\section{DISCUSSION}

Abnormal immunohistochemical expression of p53 was detected in $35.2 \%$ in the present Brazilian group of HCC patients, in a remarkable similarity to the findings from PAIVA et al., reporting $\mathrm{p} 53$ immunoexpression in 5/15 HCC cases also from São Paulo, Brazil ${ }^{51}$. Several studies have indicated a relation between the p53 gene alteration and the development of $\mathrm{HCC}^{41}$. This alteration occurs in the HCC of different causes, including $\mathrm{HBV}$ and HCV infection, aflatoxin intake, hemochromatosis, and alfa1antitrypsin $1,17,30,56$. This alteration in p53 is linked to cellular events which are accompanied by increased expression of several growth factors that enhance the survival of carcinogen-activated cells by suppressing apoptosis and increasing elements entering the cell cycle ${ }^{17,45}$. Trying to take this correlation in order to improve the diagnosis and the prognosis knowledge of this tumor, we studied the p53 immuno-expression using a immunohistochemical method with monoclonal antibodies to different epitopes of N-terminal region of p53 DO-7, 1801 and DO-1.

We could not find significant differences in the p53 expression in cirrhotic versus noncirrhotic patients with HCC contrasting to results of high-throughput gene analysis using cDNA microarrays study which supported the idea of different genetic alterations in $\mathrm{HCC}$ with or without cirrhosis $^{53}$.

Higher detection of $\mathrm{p} 53$ alteration in advanced grade tumor (GRADE III-IV) and absence of that alteration in dysplastic and adenomatous hyperplastic areas in the vicinity of the tumor are in agreement with a 


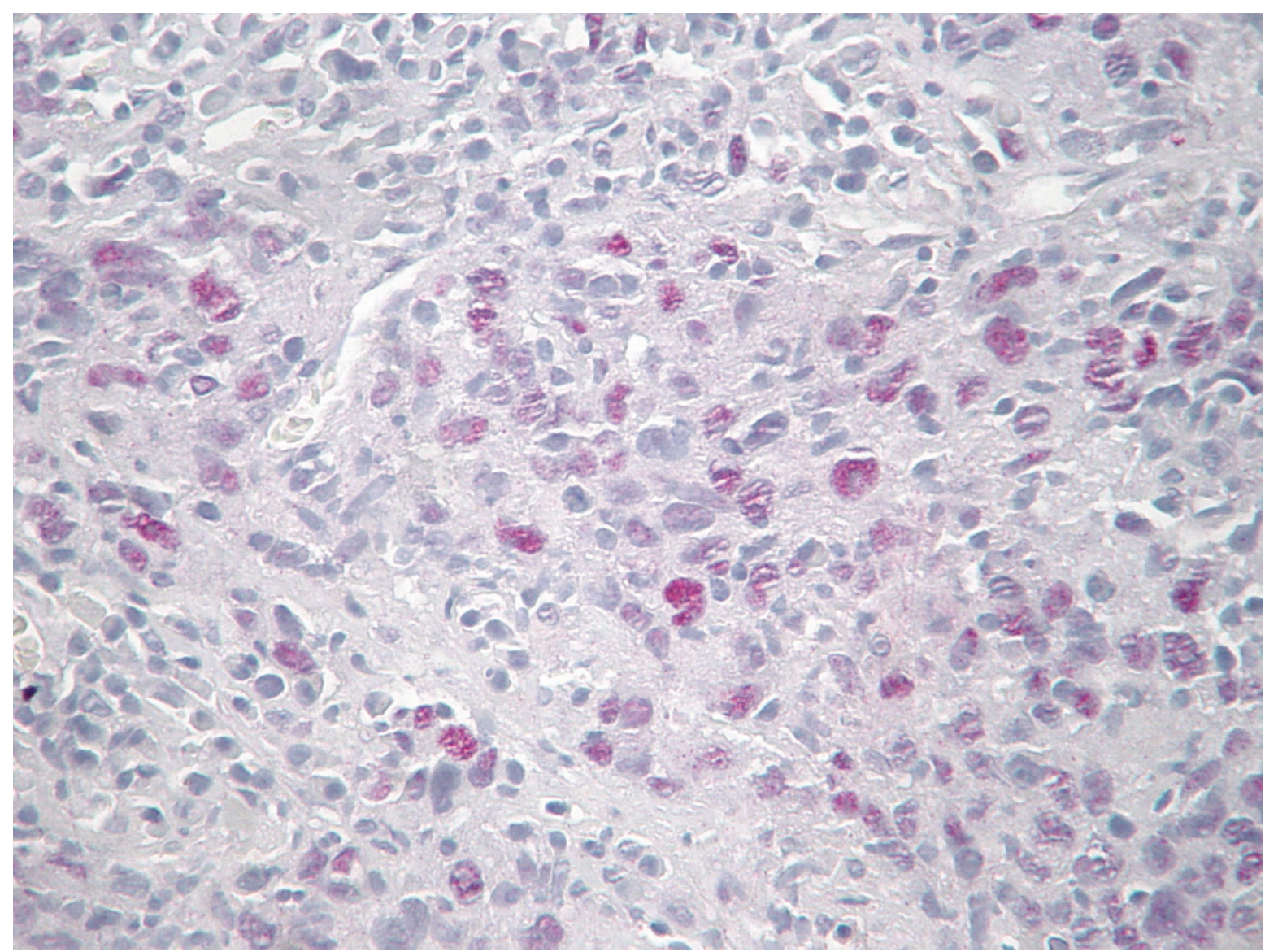

Fig. 1 - Immuno-expression of p53 is abundant in nuclei, whereas cytoplasmic immunostaining is found in occasional neoplastic cells (DO-7, Envision Alk. Phosphatase, x 200).

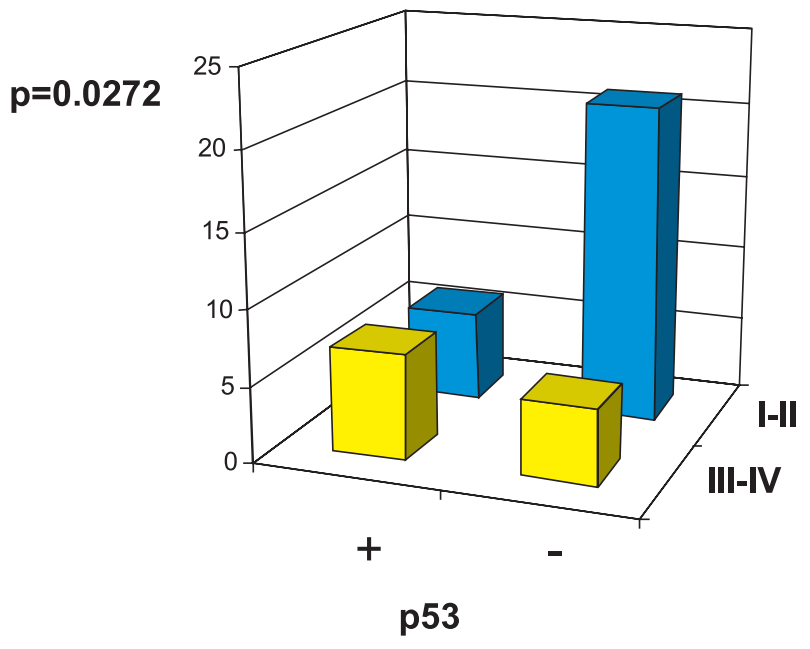

Fig. 2 - p53 immuno-expression versus histological grade.

research which shows $\mathrm{p} 53$ gene alteration of $15 \%$ and $52 \%$ in moderately and poorly differentiated HCCs respectively and not at all in well differentiated HCC. Since in the preferential pathway for liver cell carcinogenesis, early/small hepatocellular carcinomas are usually well- differentiated (grades I and II) whereas advanced/large carcinomas are preferentially grades III-IV, this finding further demonstrates that p53 alterations are late event in hepatocarcinogenesis. Another study that examined p53 gene by PCR-RFLP also corroborates to this conclusion, showing a p53 mutation rate of $10 \%, 55.2 \%$ and $80.8 \%$ in the well-, moderately- and poorly-differentiated HCC respectively ${ }^{32}$. In contrast, it was demonstrated that in animals the $\mathrm{p} 53$ gene mutations is present in initial hepatocarcinogenesis ${ }^{22}$, and HUANG et al. showed that in humans a serine substitution at codon 249 of the p53 gene might serve as a new early diagnostic marker for $\mathrm{HCC}^{29}$.

Moreover, it was showed in a Japanese study that the spectrum of p53 mutation did not differ among HCCs in relation to the type of hepatitis virus infection, sex, age, and background liver disease of patients, tumor size or presence of metastasis, however incidence and site were significantly associated with the degree of differentiation of cancer cells. Using Single Strand Conformation Polymorphism analysis, it was found $54 \%$ of p53 mutation in poorly differentiated HCC while the mutation was less frequent $(21 \%)$ in well or moderately differentiated $\mathrm{HCC}^{46}$.

p53 gene mutation is suggested to occur independently of the type of infection or status of preexisting liver disease, as well showed in our research where $\mathrm{HBV}, \mathrm{HCV}$ or alcohol was not a factor of difference in the mp53 expression ${ }^{46}$. However, in a recent study, ALTAF found p53 


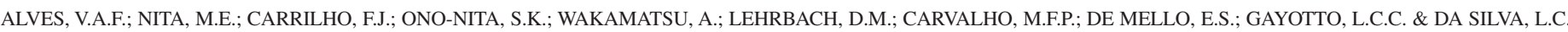
- p53 immunostaining pattern in Brazilian patients with hepatocellular carcinoma. Rev. Inst. Med. trop. S. Paulo, 46(1):25-31, 2004.

immunoexpression in $52 \%$ of cases and $53 \%$ of them were having anti hepatitis B surface antigen positivity, detected in their serum and $23 \%$ were having hepatitis $\mathrm{C}$ antibodies positive ${ }^{2}$. On the other hand, DING et al. found only 20 p53 point mutation at exon 7 in 239 HCC samples examined ${ }^{16}$.

In a study using immunohistochemical detection for mutant p53 protein with monoclonal antibody PAb1801, TERAMOTO et al. found p53 overexpression in 22 tumours $(31 \%)$ but in none of the non-tumorous liver specimens ${ }^{54}$. Overexpression of p53 was more frequent in poorly differentiated tumours $(p=0.01)$, in tumours $>5 \mathrm{~cm}(p=0.05)$, and in those presenting giant cells $(p=0.03)$. No significant correlation with hepatitis B or C status, background liver disease was detected, suggesting that p53 mutation in $\mathrm{HCC}$ was a late event in $\mathrm{HCC}^{54}$. The present study, along with other papers further corroborate this hypothesis ${ }^{2,60}$.

In a study that has assessed p53 expression by immunoluminometric assay on liver samples from 40 patients with biopsy-proven HCV-related chronic hepatitis, was found an overexpression of p53 in $17.5 \%$ of them and this $\mathrm{p} 53$ positive group had a daily ethanol intake significantly higher in respect to that of the $\mathrm{p} 53$ negative group $(p<0.05)^{18}$. Another study found that tumors associated with alcoholism had more frequent alterations in the p53 pathway than those caused by HCV infection ${ }^{20}$. In our study, a different factor related to carcinogenesis of HCC is also evident, since no difference was found among patients with $\mathrm{HBV}, \mathrm{HCV}$ or alcoholic influence.

Regarding the less commonly reported finding of cytoplasmic p53 immunoexpression, the reproducibility of results in cases with enough sample in the block for the repetition of the reaction with the new polymer-enzyme Envision method reinforces the hypothesis that this may be an odd, but genuine localization of $\mathrm{p} 53$, as previously suggested by ZHAO et al. ${ }^{59}$ and by ZERBINI et al..$^{58}$. In a recent experiment $\mathrm{OH}$ et al. showed that bile duct ligation shifts p53 immunohistochemical expression from nuclei to cytoplasm and advocate that such shifting could play an important role in induction of apoptosis ${ }^{47}$.

\section{CONCLUSION}

In this study we tried to correlate the immunohistochemical expression of altered p53 (mp53) to the degree of alterations of hepatic cells.

We found a frequency of mp53 expression in HCC of 35.2\%, which is intermediate between data from USA (6-18\%) and Africa (40-50\%) where this alteration would be related to aflatoxin. Moreover, it was not found a significant difference between cirrhotics versus non-cirrhotics, as well as among HBV and HCV and alcoholic suggesting another triggering factor for such alteration in Brazil. The higher frequency of aberrant immuno-expression of p53 in less differentiated HCCs further demonstrates that p53 alterations are late phenomena in liver carcinogenesis.

Future studies should be aimed at mapping hot spot areas of p53 mutation as well as at assessing the possible role of other etiological agents, including toxics, such as aflatoxins and organic contaminants in HCC in Brazil.

\section{RESUMO}

\section{Expressão imunohistoquímica do p53 carcinoma hepatocelular de pacientes brasileiros}

O carcinoma hepatocelular (CHC) é um importante tipo de câncer relacionado etiologicamente a alguns vírus, carcinógenos químicos e outros fatores ambientais que causam danos crônicos ao fígado em humanos. A freqüência de mutação do gene p53 em CHC é altamente heterogênea (0$52 \%$ ) nos diversos países. OBJETIVO. O objetivo deste estudo foi determinar, imuno-histologicamente, a frequiência da expressão anômala de p53 em CHCs em pacientes cirróticos versus não-cirróticos, bem como em displasia hepática e hiperplasia adenomatosa. Para isso, foram estudados 84 pacientes com carcinoma hepatocelular ou cirrose. RESULTADOS. Foram detectadas expressões do p53 alterado em 58,3\% dos pacientes com CHC graus III-IV, contrastando com os $22,2 \%$ dos pacientes com $\mathrm{CHC}$ graus I-II $(\mathrm{p}=0,02)$. Áreas não tumorais, tanto nas proximidades do CHC como nos 30 casos de cirrose não mostraram expressão nuclear alterada do p53, mesmo nas displasias ou hiperplasias adenomatosas. Quando se considerou HBV, HCV ou alcoolismo nos casos estudados, não se encontrou diferença significativa. CONCLUSÃO. A elevada freqüência de imuno-expressão de p53 nesta população é próxima à relatada na China e África, tornando necessárias outras pesquisas para explicar as diferenças com os $\mathrm{CHC}$ estudados na Europa e na América do Norte.

\section{ACKNOWLEDGMENTS}

This paper was supported in part by the Projeto Hepatologia Hepatites / Câncer with a grant from Alves de Queiróz Family Fund for Research.

\section{REFERENCES}

1. AHSAN, H.; WANG, L.Y.; CHEN, C.J.; TSAI, W.Y. \& SANTELLA, R.M. - Variability in aflatoxin-albumin adduct levels and effects of hepatitis B and $\mathrm{C}$ virus infection and glutathione S-transferase M1 and T1 genotype. Environ. Hlth. perspect., 109: 833-837, 2001.

2. ALTAF, F.J. - Hepatocellular carcinoma. Saudi Med. J., 22: 416-418, 2001.

3. ANTHONY, P.P.; VOGEL, C.L. \& BARKER, L.F. - Liver cell dysplasia: a premalignant condition. J. clin. Path., 26: 217-223, 1973.

4. ARAKAWA, M.; KAGE, M.; SUGIHARA, S. et al. - Emergence of malignant lesions within an adenomatous hyperplastic nodule in a cirrhotic liver. Observations in five cases. Gastroenterology, 91: 198-208, 1986.

5. BOIX-FERRERO, J.; PELLIN, A.; BLESA, R.; ADRADOS, M. \& LLOMBARTBOSCH, A. - Absence of p53 gene mutations in hepatocarcinomas from a Mediterranean area of Spain. A study of 129 archival tumour samples. Virchows Arch., 434: 497-501, 1999.

6. BRESSAC, B.; KEW, M.; WANDS, J. \& OZTURK, M. - Selective G to T mutations of p53 gene in hepatocellular carcinoma from southern Africa. Nature (Lond.), 350: 429-431, 1991.

7. BUENDIA, M.A. - Genetics of hepatocellular carcinoma. Semin. Cancer Biol., 10: $185-200,2000$.

8. CARRILHO, F.J. - Carcinoma hepatocelular e cirrose hepática. Estudo caso-controle de variáveis clínicas, bioquímicas, sorológicas e morfológicas. São Paulo, 1993. (Tese de Doutorado - Faculdade de Medicina da Universidade de São Paulo). 
ALVES, V.A.F.; NITA, M.E.; CARRILHO, F.J.; ONO-NITA, S.K.; WAKAMATSU, A.; LEHRBACH, D.M.; CARVALHO, M.F.P.; DE MELLO, E.S.; GAYOTTO, L.C.C. \& DA SILVA, L.C. - p53 immunostaining pattern in Brazilian patients with hepatocellular carcinoma. Rev. Inst. Med. trop. S. Paulo, 46(1):25-31, 2004.

9. CARRILHO, F.J.; ALVES, V.A.F.; MELLO, E.S. \& VEZOZZO, D.C.P. - Carcinoma hepatocelular. In: GAYOTTO, L.C.C. \& ALVES, V.A. Doenças do fígado e das vias biliares. São Paulo, Atheneu, 2001. p. 997-1016.

10. CHALlEN, C.; LUNEC, J.; WARREN, W.; COLLIER, J. \& BASSENDINE, M.F. Analysis of the 53 tumor-suppressor gene in hepatocellular carcinomas from Britain. Hepatology, 16: 1362-1366, 1992.

11. CHEN, P.-J. \& CHEN, D.-S. - Hepatitis B virus infection and hepatocellular carcinoma: molecular genetics and clinical perspectives. Semin. Liver Dis., 19: 253-262, 1999.

12. COURSAGET, P.; DEPRIL, N.; CHABAUD, M. et al. - High prevalence of mutations at codon 249 of the p53 gene in hepatocellular carcinomas from Senegal. Brit. J. Cancer, 67: 1395-1397, 1993.

13. DE BENEDETTI, V.M.; WELSH, J.A.; TRIVERS, G.E. et al. - p53 is not mutated in hepatocellular carcinomas from Alaska Natives. Cancer Epidem. Biomarkers Prev., 4:79-82, 1995 .

14. DENG, Z.; PAN, L. \& MA, Y. - Sequence alterations in p53 gene of hepatocellular carcinoma from high aflatoxin risk area in Guangxi. Zhonghua Zhong Liu Za. Zhi., 19: 18-21, 1997

15. DIAMANTS, I.D.; MCGANDY, C.; CHEN, T.J. et al. - A new mutational hot-spot in the p53 gene in human hepatocellular carcinoma. J. Hepatol., 20: 553-556, 1994.

16. DING, X.; PARK, Y.N.; TALTAVULL, T.C. et al. - Geographic characterization of hepatitis virus infections, genotyping of hepatitis B virus, and p53 mutation in hepatocellular carcinoma analyzed by in situ detection of viral genomes from carcinoma tissues: comparison among six different countries. Jap. J. infect. Dis., 56: 12-18, 2003.

17. DOMINGUES-MALAGON, H. \& GAYTAN-GRAHAM, S. - Hepatocellular carcinoma: an update. Ultrastruct. Path., 25: 497-516, 2001.

18. DONATO, F.; BOFFETTA, P. \& PUOTI, M. - A meta-analysis of epidemiological studies on the combined effect of hepatitis $\mathrm{B}$ and $\mathrm{C}$ virus infections in causing hepatocellular carcinoma. Int. J. Cancer, 75: 347-354, 1998.

19. DOWELL, S.P. \& HALL, P.A. - The p53 tumour suppressor gene and tumour prognosis: is there a relationship? J. Path., 177: 221-224, 1995.

20. EDAMOTO, Y.; HARA, A.; BIERNAT, W. et al. - Alterations of RB1, p53 and Wnt pathways in hepatocellular carcinomas associated with hepatitis $\mathrm{C}$, hepatitis $\mathrm{B}$ and alcoholic liver cirrhosis. Int. J. Cancer, 106: 334-341, 2003.

21. FISHER, C.J.; GILLETT, C.E.; VOJTESEK, B.; BARNES, D.M. \& MILLIS, R.R. Problems with 553 immunohistochemical staining: the effect of fixation and variation in the methods of evaluation. Brit. J. Cancer, 69: 26-31, 1994.

22. FU, Y.; DENG, W.; KAWARADA, Y. et al. - Mutation and expression of the p53 gene during chemical hepatocarcinogenesis in F344 rats. Biochim. Biophys. Acta, 1628: 40-49, 2003.

23. FUJIMOTO, Y.; HAMPTON, L.L.; WIRTH, P.J. et al. - Alterations of tumor suppressor genes and allelic losses in human hepatocellular carcinomas in China. Cancer Res., 54: 281-285, 1994.

24. HAYASHI, H.; SUGIO, K.; MATSUMATA, T. et al. - The clinical significance of p53 gene mutation in hepatocellular carcinomas from Japan. Hepatology, 22: 1702-1707, 1995.

25. HOLLSTEIN, M.C.; WILD, C.P.; BLEICHER, F. et al. - p53 mutations and aflatoxin B1 exposure in hepatocellular carcinoma patients from Thailand. Int. J. Cancer, 53: 51$55,1993$.

26. HONDA, K.; SBISA, E.; TULLO, A. et al. - p53 mutation is a poor prognostic indicator for survival in patients with hepatocellular carcinoma undergoing surgical tumour ablation. Brit. J. Cancer, 77: 776-782, 1998.

27. HSU, I.C.; METCALF, R.A.; SUN, T. et al. - Mutational hotspot in the p53 gene in human hepatocellular carcinomas. Nature (Lond.), 350: 427-428, 1991.
28. HU, T.H.; HUANG, C.C.; LIN, P.R. et al. - Expression and prognostic role of tumor suppressor gene PTEN/MMAC1/TEP1 in hepatocellular carcinoma. Cancer, 97: 1929-1940, 2003.

29. HUANG, X.H.; SUN, L.H.; LU, D.D. et al. - Codon 249 mutation in exon 7 of p53 gene in plasma DNA: maybe a new early diagnostic marker of hepatocellular carcinoma in Qidong risk area, China. Wld. J. Gastroent., 9: 692-695, 2003.

30. HUO, T.I.; WANG, X.W.; FORGUES, M. et al. - Hepatitis B virus X mutants derived from human hepatocellular carcinoma retain the ability to abrogate p53-induced apoptosis. Oncogene, 20: 3620-3628, 2001.

31. HUSSAIN, S.P. \& HARRIS, C.C. - Molecular epidemiology and carcinogenesis: endogenous and exogenous carcinogens. Mutation Res., 462: 311-322, 2000.

32. JIANG, W.; LU, Q. \& PAN, G. - p53 gene mutation in hepatocellular carcinoma. Zhonghua Wai Ke. Za. Zhi., 36: 531-532, 1998.

33. KAZACHKOV, Y.; KHAOUSTOV, V.; YOFFE, B. et al. - p53 abnormalities in hepatocellular carcinoma from United States patients: analysis of all 11 exons. Carcinogenesis, 17: 2207-2212, 1996.

34. KOJIRO, M. \& NAKASHIMA, T. - Pathology of hepatocellular carcinoma. In: OKUDA, K. \& ISHAK, K.G. Neoplasms of the liver. Tokyo, Springer-Verlag, 1987. p. 81-104.

35. KONDO, F.; WADA, K. \& KONDO, Y. - Morphometric analysis of hepatocellular carcinoma. Virchows Arch. A Path. Anat. Histopath., 413: 425-430, 1988.

36. KRESS, S.; JAHN, U.R.; BUCHMANN, A.; BANNASCH, P. \& SCHWARZ, M. - p53 mutations in human hepatocellular carcinomas from Germany. Cancer Res., 52: 3220-3223, 1992.

37. LAURENT-PUIG, P.; FLEJOU, J.F.; FABRE, M. et al. - Overexpression of p53: a rare event in a large series of white patients with hepatocellular carcinoma. Hepatology, 16: 1171-1175, 1992.

38. LIBBRECHT, L.; CRANINX, M.; NEVENS, F.; DESMET, V. \& ROSKAMS, T. Predictive value of liver cell dysplasia for development of hepatocellular carcinoma in patients with non-cirrhotic and cirrhotic chronic viral hepatitis. Histopathology, 39: $66-73,2001$

39. MELLO, E.S. - Macronódulos em fígados cirróticos: estudo morfológico com ênfase nos aspectos macroscópicos, proliferação e apoptose. São Paulo, 2001. (Tese de Doutorado - Faculdade de Medicina da Universidade de São Paulo).

40. MURAKAMI, Y.; HAYASHI, K.; HIROHASHI, S. \& SEKIYA, T. - Aberrations of the tumor suppressor p53 and retinoblastoma genes in human hepatocellular carcinomas. Cancer Res., 51: 5520-5525, 1991.

41. NAKAMURA, T.; IWAMURA, Y.; KANEKO, M. et al. - Deletions and rearrangements of the retinoblastoma gene in hepatocellular carcinoma, insulinoma and some neurogenic tumors as found in a study of 121 tumors. Jap. J. clin. Oncol., 21: 325-329, 1991.

42. NG, I.O.; SRIVASTAVA, G.; CHUNG, L.P.; TSANG, S.W. \& NG, M.M. - Overexpression and point mutations of 53 tumor suppressor gene in hepatocellular carcinomas in Hong Kong Chinese people. Cancer, 74: 30-37, 1994.

43. NISHIDA, N.; FUKUDA, Y.; KOKURYU, H. et al. - Accumulation of allelic loss on arms of chromosomes $13 \mathrm{q}, 16 \mathrm{q}$ and $17 \mathrm{p}$ in the advanced stages of human hepatocellular carcinoma. Int. J. Cancer, 51: 862-868, 1992.

44. NITA, M.E.; ALVES, V.A F.; CARRILHO, F.J. et al. - Molecular aspects of hepatic carcinogenesis. Rev. Inst. Med. trop. S. Paulo, 44: 39-48, 2002.

45. NITA, M.E.; NAGAWA, H.; TOMINAGA, O. et al. - p21Waf1/Cip1 expression is a prognostic marker in curatively resected esophageal squamous cell carcinoma, but not p27Kip1, p53, or Rb. Ann. surg. Oncol., 6: 481-488, 1999. 
46. ODA, T.; TSUDA, H.; SCARPA, A.; SAKAMOTO, M. \& HIROHASHI, S. - p53 gene mutation spectrum in hepatocellular carcinoma. Cancer Res., 52: 6358-6364, 1992.

47. OH, S.H.; YAN, K.J.; NAN, J.X.; SOHN, D.H. \& LEE, B.H. - Changes in expression and immunolocalization of protein associated with toxic bile salts-induced apoptosis in rat hepatocytes. Arch. Toxicol., 77: 110-115, 2003.

48. OHTA, G. \& NAKANUMA, Y. - Comparative study of three nodular lesions in cirrhosis: adenomatoid hyperplasia, adenomatoid hyperplasia with intermediate lesion and small hepatocellular carcinoma. In: OKUDA, K. \& ISHAK, K.G. Neoplasms of the liver. Tokyo, Springer-Verlag, 1987. p. 177-187.

49. OKUDA, K. - Hepatocellular carcinoma. J. Hepat., 32: 225-237, 2000.

50. OZTURK, M. - Genetic aspects of hepatocellular carcinogenesis. Semin. Liver Dis., 19: 235-242, 1999.

51. PAIVA, C.; OSHIMA, C.T.; LANZONI, V.P. \& FORONES, N.M. - Apoptosis, PCNA and p53 in hepatocellular carcinoma. Hepatogastroenterology, 49: 1058-1061, 2002.

52. SCORSONE, K.A.; ZHOU, Y.Z.; BUTEL J.S. \& SLAGLE, B.L. - p53 mutations cluster at codon 249 in hepatitis B virus-positive hepatocellular carcinomas from China. Cancer Res., 52: 1635-1638, 1992.

53. TANNAPFEL, A. \& WITTEKIND, C. - Genes involved in hepatocellular carcinoma: deregulation in cell cycling and apoptosis. Virchows Arch., 440: 345-352, 2002.
54. TERAMOTO, T.; SATONAKA, K.; KITAZAWA, S. et al. - p53 gene abnormalities are closely related to hepatoviral infections and occur at a late stage of hepatocarcinogenesis. Cancer Res., 54: 231-235, 1994.

55. VESEY, D.A.; HAYWARD, N.K. \& COOKSLEY, W.G. - p53 gene in hepatocellular carcinomas from Australia. Cancer Detect. Prev., 18: 123-130, 1994.

56. WONG, N.; LAI, P.; PANG, E. et al. - Genomic aberrations in human hepatocellular carcinomas of differing etiologies. Clin. Cancer Res., 6: 4000-4009, 2000.

57. WYNFORD-THOMAS, D. - p53 in tumour pathology: can we trust immunocytochemistry? J. Path., 166: 329-330, 1992.

58. ZERBINI, M.C.; SREDNI, S.T.; GRIER, H. et al. - Primary malignant epithelial tumors of the liver in children: a study of DNA content and oncogene expression. Pediat. Dev. Path., 1: 270-280, 1998.

59. ZHAO, M.; ZHANG, N.X.; LAISSUE, J.A. \& ZIMMERMANN, A. Immunohistochemical analysis of p53 protein overexpression in liver cell dysplasia and in hepatocellular carcinoma. Virchows Arch., 424: 613-621, 1994.

60. ZHOU, F.; WANG, J.; LEI, B. et al. - Detection of p53 gene mutations in hepatocellular carcinomas. Hua Xi Yi Ke Da Xue Xue, 28: 50-54, 1997.

Received: 9 September 2003

Accepted: 8 December 2003 